\title{
Renin-Angiotensin System Hyperactivation Can Induce Inflammation and Retinal Neural Dysfunction
}

\author{
Toshihide Kurihara, ${ }^{1,2,3}$ Yoko Ozawa, ${ }^{1,2}$ Susumu Ishida, ${ }^{2,4}$ \\ Hideyuki Okano, ${ }^{5}$ and Kazuo Tsubota ${ }^{1}$ \\ ${ }^{1}$ Department of Ophthalmology, Keio University School of Medicine, 35 Shinanomachi, Shinjyuku-ku, Tokyo 160-8582, Japan \\ ${ }^{2}$ Laboratory of Retinal Cell Biology, Keio University School of Medicine, 35 Shinanomachi, Shinjyuku-ku, Tokyo 160-8582, Japan \\ ${ }^{3}$ Department of Cell Biology, The Scripps Research Institute, MB 28, 10550 North Torrey Pines Road, La Jolla, CA 92037, USA \\ ${ }^{4}$ Department of Ophthalmology, Hokkaido University Graduate School of Medicine, N-15, W-7, Kita-ku, Sapporo 060-8638, Japan \\ ${ }^{5}$ Department of Physiology, Keio University School of Medicine, 35 Shinanomachi, Shinjyuku-ku, Tokyo 160-8582, Japan
}

Correspondence should be addressed to Toshihide Kurihara, kurihara@2009.jukuin.keio.ac.jp

Received 15 October 2011; Revised 9 December 2011; Accepted 4 January 2012

Academic Editor: Michelle C. Callegan

Copyright (c) 2012 Toshihide Kurihara et al. This is an open access article distributed under the Creative Commons Attribution License, which permits unrestricted use, distribution, and reproduction in any medium, provided the original work is properly cited.

\begin{abstract}
The renin-angiotensin system (RAS) is a hormone system that has been classically known as a blood pressure regulator but is becoming well recognized as a proinflammatory mediator. In many diverse tissues, RAS pathway elements are also produced intrinsically, making it possible for tissues to respond more dynamically to systemic or local cues. While RAS is important for controlling normal inflammatory responses, hyperactivation of the pathway can cause neural dysfunction by inducing accelerated degradation of some neuronal proteins such as synaptophysin and by activating pathological glial responses. Chronic inflammation and oxidative stress are risk factors for high incidence vision-threatening diseases such as diabetic retinopathy (DR), age-related macular degeneration (AMD), and glaucoma. In fact, increasing evidence suggests that RAS inhibition may actually prevent progression of various ocular diseases including uveitis, DR, AMD, and glaucoma. Therefore, RAS inhibition may be a promising therapeutic approach to fine-tune inflammatory responses and to prevent or treat certain ocular and neurodegenerative diseases.
\end{abstract}

\section{Introduction}

Most visual disorders occur in the retina, which is a part of the central nervous system (CNS) and consists of neurons, glia, pigment epithelium (RPE), and blood vessels. Currently, diabetic retinopathy (DR), age-related macular degeneration (AMD), and glaucoma are the top causes of blindness in the developed countries. These diseases can occur when local or systemic neuronal and vascular homeostasis mechanisms are dysregulated. The highest risk factor for many of these diseases is aging [1-3], and as is the case with other age-related diseases such as Alzheimer's disease, cardiovascular disease, cancer, arthritis, osteoporosis, and hypertension, accumulating evidence suggests that chronic inflammation and oxidative stress can accelerate or promote disease progression [4-6].
The renin-angiotensin system (RAS) is classically known as a systemic blood-pressure-regulating system. However, it is becoming widely recognized as an inflammation regulator as well. Independent of systemic RAS, tissue intrinsic RASs have been identified in various tissues (including the retina) and are important for maintaining local homeostasis. Elements of the RAS pathway are highly conserved in many species including invertebrates and humans demonstrating that its functions are evolutionarily conserved, although spatial expression patterns differ slightly between different species [7].

We have reported that angiotensin II type 1 receptor blocker (ARB) suppresses retinal neural dysfunction in animal models of acute inflammation [8] or diabetes [9]. Other groups and our own have also reported that ARBs can protect retinal vascular inflammation [10-19] and neuronal 


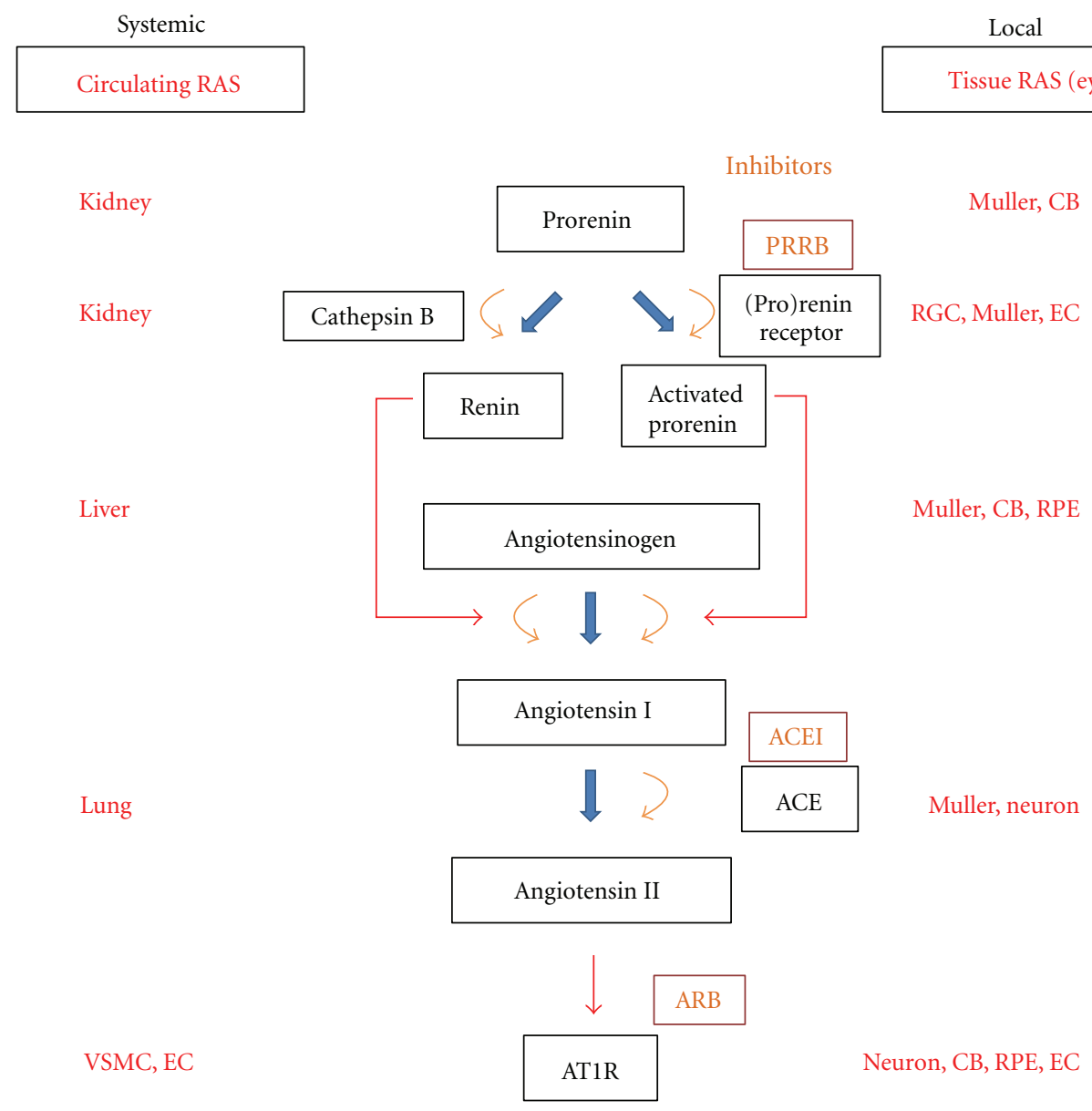

FIGURE 1: Circulating and tissue renin-angiotensin system (RAS). VSMC: vascular smooth muscle cell, EC: endothelial cell, PRRB: (pro)renin receptor blockers, ACEI: angiotensin-converting enzyme inhibitors, ARB: angiotensin II type 1 receptor blockers, AT1R: angiotensin II type 1 receptor, CB: ciliary body, RPE: retinal pigment epithelium.

apoptosis [20-23]. Furthermore, it was recently reported by two independent groups that daily oral administration of ARB may prevent the progression of diabetic retinopathy in randomized multicenter clinical trials [24-26]. In this paper we will summarize these findings and other studies demonstrating that RAS modulation may prevent ocular pathogenesis. We will also outline the similarities and differences between retinal and brain RAS. Lastly, we will describe the potential mechanisms through which RAS inhibition may preserve neuronal function and viability while combating ocular diseases.

\section{RAS as an Inflammatory Cascade}

Renin was discovered as a hypertensive agent in rabbit kidneys in 1898. It was later found to induce the release of a vasoconstrictive agent in experimental models of hypertension induced by renal ischemia [27]. Two independent groups identified the end product of this hypertensive cascade in 1939 and named it "hypertension" [28] or "angiotonin" [29]. It has since been renamed "angiotensin" [30]. The RAS pathway as we know it today began to take shape once angiotensin-converting enzyme (ACE) was identified in 1956 [31]. We now know that once renin is proteolytically processed from its precursor prorenin by proteases and released from the kidney, it converts angiotensinogen to angiotensin I in the liver. Angiotensin I is finally converted to angiotensin II by ACE which is predominantly expressed in vascular endothelial cells (ECs) and is located in highly vascularized tissues such as the lung (Figure 1). Angiotensin II stimulates vascular smooth muscle cells (VSMCs) that line endothelial cells to contract and induce vasoconstriction.

There are two primary receptors for angiotensin II: angiotensin II type 1 receptor (AT1R) and AT2R; AT1R appears to exert predominant functions in blood vessels. Generally, AT1R signaling normally induces vasoconstriction while AT2R signaling induces vasodilation. However, the roles of AT1R and AT2R in pathophysiological conditions are currently under debate [32-34]. AT1R is a seven-transmembrane $\mathrm{G}$ protein-coupled receptor $[35,36]$. Once stimulated in VSMCs G proteins activate phospholipase C (PLC) and inositol-1,4,5-triphosphate (IP3) to open calcium channels in the endoplasmic reticulum [37]. As a result, increase of 
cytosolic calcium induces phosphorylation of myosin light chain, VSMC contraction, and vasoconstriction $[38,39]$.

Independent of systemically circulating angiotensin II (circulating RAS), most RAS components, including ACE, were also found to be locally expressed in many tissues [40]. This observation resulted in the hypothesis that in addition to being converted in particular organs for systemic circulation, angiotensin II could also be synthesized in peripheral tissues (tissue RAS) where it would exert its effect locally. Tissue RAS elements were identified in various organs including heart [41], kidney [42], adrenal gland [43], brain [44], and retina (see details below). An important molecule involved with tissue RAS is (pro)renin receptor which interacts with prorenin to exert enzymatic activity of renin without the conventional proteolysis of the prorenin prosegment $[45,46]$. (Pro)renin receptor can be detected in major organs but not in circulation indicating that this molecule may play a critical role in the activation of tissue RAS [46]. Thus tissue RAS may be important for fine-tuning global RAS activity or for acting intrinsically to respond to localized insults. However, (pro)renin receptor may also function independent of renin activation as a member of the Wnt receptor complex to regulate Wnt/ß-catenin pathway activity [47].

In addition to its critical physiological functions, RAS dysregulation can lead to pathogenesis. In various cardiovascular cell-type RASs hyperactivation can induce pathogenic cell migration, hypertrophy, fibrosis, disrupt cell adhesion and ectopic extracellular matrix (ECM) deposition. AT1R signaling directly activates key signaling pathways for cell growth and hypertrophy including JAK/STAT (janus kinase/signal transducer and activator of transcription) [48, 49], ERK (extracellular-signal-regulated kinase) $1 / 2$ [50-52], and p38 MAPK (mitogen-activated protein kinase) [53]. Indeed, angiotensin II/AT1R signaling can potentiate oxidative stresses and inflammatory responses by activation of $\mathrm{NAD}(\mathrm{P}) \mathrm{H}$ (nicotinamide adenine dinucleotide phosphate) oxidases [5457]. Angiotensin II can also activate EGFR (epidermal growth factor receptors) and induces fibronectin synthesis and TGF $\beta$ (transforming growth factor beta) activity to promote fibrosis and ECM formation $[58,59]$. AT1R signaling can activate $\mathrm{NF} \kappa \mathrm{B}$ (nuclear factor kappa-light-chain-enhancer of activated B cells) [60-62] and AP-1 (activator protein 1) to initiate transcription of multiple proinflammatory genes [61, $63,64]$. AT1R also induces accumulation, adhesion, and infiltration of inflammatory cells via activation of PAI-1 (plasminogen activator inhibitor-1) [65] and MCP-1 (monocyte chemotactic protein-1) [62] to promote atherosclerosis [66]. Taken together, these findings provide strong evidence that RAS is not just a regulator of blood pressure, but also regulates an inflammatory cascade.

The effects of circulating and tissue RAS can be controlled with RAS inhibitors. After the first ACE inhibitor (ACEI) was developed [67], many other RAS inhibitors including ARB $[68,69]$ have been established and approved for commercial use as hypertension drugs (Figure 1). RAS inhibition not only prevents hypertension but also protects tissues against injury by limiting the potency of deleterious inflammatory responses. Since aging is considered to be, in part, the result of chronic inflammation [70], it may not be too surprising that the use of RAS inhibitors or genetic deletion of AT1R has potential to extend the life span in hypertensive [71-73] or normotensive [74] mammals.

\section{Brain and the Retinal RAS}

In addition to regulating vasoconstriction, another important physiological function of RAS is osmoregulation in the CNS (e.g., water and sodium intake, sympathetic activity, and release of vasopressin) [75-77]. AT1R is expressed in brain neurons and mediates osmoregulation [76] by stimulating the release of vasopressin in the pituitary gland and signaling the kidney to conserve water [76]. Furthermore angiotensin II/AT1R signaling in the brain forces individuals to stimulate increased thirst and consume more drinking water [77]. Since angiotensin II has a high molecular weight, it does not cross the blood-brain barrier (BBB) [78]. Therefore intrinsic RAS networks must be responsible for inducing the dipsogenic activity. Additionally, every component of the RAS pathway including angiotensinogen, ACE, and angiotensin II receptors is expressed in the brain [75, 76, 79-81]. Brain RAS can also become dysregulated; this has been shown to induce oxidative stress and inflammation [82]. However, RAS inhibitors have neuroprotective effects in brain inflammation and ischemia without inducing antihypertension (see detail below).

The retina also has an intrinsic tissue RAS. In the eye, prorenin protein and renin activity can be detected in the vitreous fluid [83-85] and prorenin mRNA has been detected in Muller glia [86] and in the ciliary body (CB) cells [87]. (Pro)renin receptor is expressed in ECs, Muller glia, and retinal ganglion cells (RGCs) $[88,89]$. Angiotensinogen is found in CB [90], Muller glia [91], and RPE [92]. ACE is synthesized in the neural retina $[93,94]$ and can be detected in RGCs, photoreceptors [95], and Muller glia [96]. Angiotensin II, the final product of RAS, can be detected in the vitreous fluid [97] and in the neural retina [98]. Interestingly, the normal concentration of angiotensin II in ocular fluid is higher than in plasma [97], confirming the existence of tissue RAS in the eye.

In the retina, angiotensin II receptors are detected both in ECs and in neuronal cells, which are located outside and inside of the blood-retina barrier (BRB), respectively $[8,92,99$, $100]$. AT1R is found in the presynaptic terminals of photoreceptors and of interneurons in the retina [8] as well as in neurons of the brain $[101,102]$ (Figure 2). AT1R is also expressed in RGCs [103], although the physiological function of AT1R in the neural retina is not fully understood. Systemic administration of ACEI negatively influences cat and human neural functions measured by electroretinograms (ERG) in both systemic blood-pressure-dependent [104] and -independent manners $[105,106]$. Additionally, angiotensin II increases voltage-dependent calcium currents in cultured RGCs [103]. Therefore ocular RAS may act as a physiological neuromodulator.

AT2R is also expressed in the retina [8] but much less is known how it functions in the eye. Polymorphisms in the AT2R gene may be linked to glaucoma [107] or diameter of the retinal arterioles [108]. 


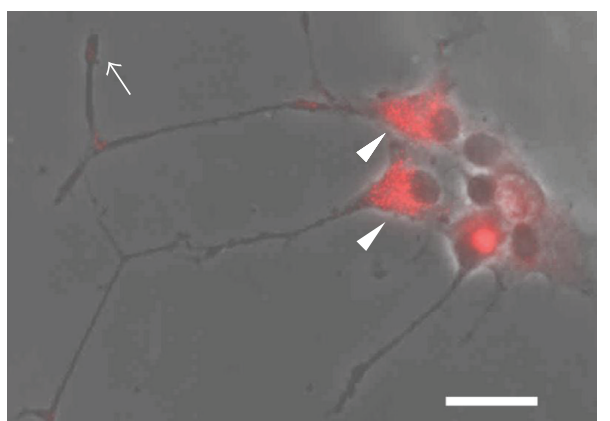

FIGURE 2: AT1R expression in a neuronal cell line. Immunohistochemistry for angiotensin II type 1 receptor (AT1R) in PC12D cells. Note that AT1R is detected in presynaptic terminal (arrow) or soma (arrow head). Scale bar: $20 \mu \mathrm{m}$.

\section{RAS and Ocular Diseases}

4.1. Uveitis. Increasing evidence suggests that RAS activity and inflammation may be associated with various ocular diseases, and, therefore, RAS inhibitors may be effective therapeutic agents. Several lines of evidences suggest that RAS inhibition is an effective treatment for uveitis $[8,12,17,18,88]$. Endotoxin-induced uveitis (EIU) is induced with intraperitoneal injections of lipopolysaccharide (LPS); this results in upregulated expression of proinflammatory and adhesion molecules such as ICAM-1 (intercellular adhesion molecule 1), MCP-1, IL-6 (interleukin 6), and IFN- $\gamma$ (interferongamma) $[17,88]$. These molecules are also upregulated in experimental autoimmune uveoretinitis (EAU) models generated by immunizing animals with interphotoreceptor retinoid-binding protein (IRBP) [18]. The upregulation of these molecules, however, can be inhibited with ARB or (pro)renin receptor blocker (PRRB). (PRRB is an experimental decoy peptide that contains "handle" region sequence of ( $p r o$ )renin receptor.) RAS inhibition also suppresses retinal leukocyte stasis, CD4+ T-cell activation $[17,18,88]$. Furthermore, RAS inhibition suppresses gliosis by preventing STAT3 activation [8]. Lastly, when the expression levels of RAS pathway components are examined in EIU, prorenin, (pro)renin receptor [88], angiotensin II [8], and AT1R [17] levels are elevated in the retina. These findings suggest that heightened inflammatory responses in the eye and RAS activation are strongly correlated.

4.2. Chronic Inflammation and Eye Diseases. Besides being correlated with classically acute inflammation cases such as uveitis, one of the largest risk factors for developing prevalent and vision-threatening diseases such as DR, AMD, and glaucoma is aging [1-3]. These age-related eye diseases [109, 110] and others $[5,6]$ are now known to be caused (at least partially) by chronic inflammation and oxidative stress. Since RAS inhibition may prolong the life spans of hypertensive [71-73] or normotensive [74] mammals, it is logical that agerelated eye diseases may be prevented or treated by suppressing inflammation and oxidative stress. The main pathological event of DR and AMD is abnormal neovascularization and VEGF (vascular endothelial growth factor) has been known to be a large contri-butor for them [111-113]. VEGF

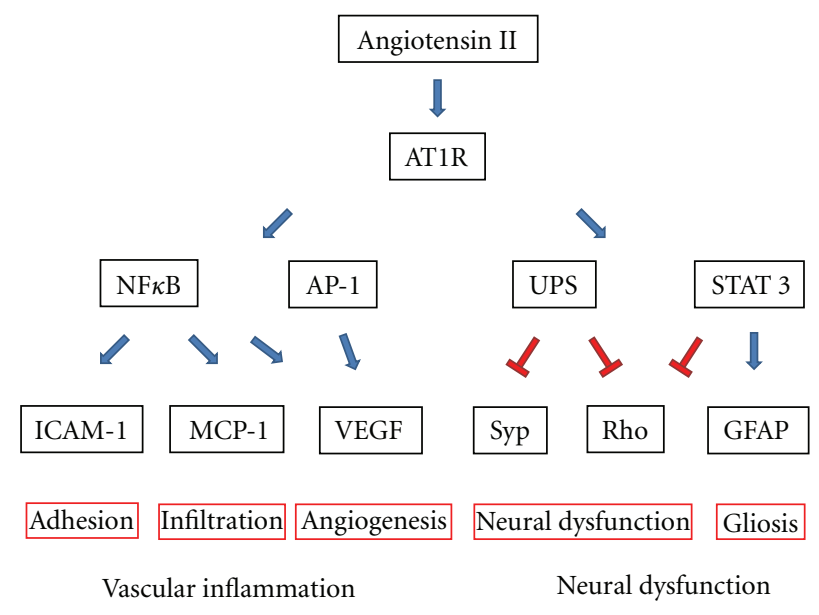

FIGURE 3: Downstream of AT1R in vascular inflammation and neural dysfunction. NFאB: nuclear factor kappa-light-chain-enhancer of activated B cells, AP-1: activator protein 1, UPS: ubiquitin-proteasome system, STAT3: signal transducer and activator of transcription 3, ICAM-1: intercellular adhesion molecule 1, MCP-1: monocyte chemotactic protein 1, VEGF: vascular endothelial growth factor, Syp: synaptophysin, Rho: rhodopsin, GFAP: glial fibrillary acidic protein.

is a potent angiogenic factor and an inflammatory cytokine that induces the accumulation, adhesion, and infiltration of leukocytes $[114,115]$. Inflammatory response in the retina can promote tissue ischemia by inducing vascular regression (vaso-obliteration) and also pathological angiogenesis [116]. Angiotensin II can induce upregulation of VEGF receptor (VEGFR)-2 and angiopoietin-2 in retinal ECs [117, 118] and VEGF in retinal pericytes [119] (Figure 3). Oxygen-induced retinopathy (OIR) is an animal model induced by continual aeration with $75-80 \%$ oxygen in early postnatal stages. OIR animals develop stereotypical phenotypes and is useful to evaluate vaso-obliteration and pathological angiogenesis (tu$\mathrm{ft}$ formation) in the developing retina [120] which is largely re-gulated by VEGF [121]. This phenotype can be prevented with RAS inhibitors ACEI [122, 123], ARB [15], or PRRB $[89,124]$ that prevent pathological angiogenesis in OIR. The use of ARB and PRRB has the added benefit of suppressing abnormal angiogenesis without suppressing physiological vascular regeneration $[15,124]$. In animals exposed to OIR RAS inhibitors may function to prevent gene expression of proinflammatory molecules and prevent leukocyte infiltration. Infiltration of VEGF-expressing inflammatory cells into the vitreous cavity is thought to induce pathological angiogenesis by causing ECs to grow in the wrong direction [115].

4.3. Diabetic Retinopathy (DR). DR is one of the leading causes of blindness in the world [3]. It is characterized by vascular loss due to hyperglycemia and inflammation due to oxidative stress and AGEs (advanced glycation end products) accumulation. In severe cases hypoxia induces abnormal neovascularization (proliferative diabetic retinopathy, PDR) in addition to hyperpermeability (diabetic macular edema; DME). Prorenin [83] and angiotensin II $[125,126]$ are found 
to be increased in the vitreous humor of PDR and DR patients. RAS may potentiate the vascular phenotype of DR by upregulating VEGF/VEGFR-2 signaling (through angiotensin II) $[118,119]$ thereby inducing neovascularization and promoting blood vessel permeability. In fact, VEGF was initially named "vascular permeability factor" (VPF) [127].

Multiple attempts have been made to treat DR with RAS inhibitors. Although in one study ACEI administration seemed to attenuate retinal hyperpermeability in diabetic patients [128], interpretations of these studies are still being actively debated $[129,130]$. However, recently three independent groups showed that ARB prevents BRB breakdown in animal models [131-133]. In 1998 and 2008, the results of randomized double-blind placebo-controlled trials using ACEI or ARB to treat DR were released from the EUCLID (EURODIAB Controlled Trial of Lisinopril in Insulin-Dependent Diabetes; ACEI treatment) [134] and DIRECT (Diabetic Retinopathy Candesartan Trial; ARB treatment) [24, 25]. Afterwards, RASS (Renin-Angiotensin System Study) in which both inhibitors were tested in DR patients was also released [26]. Large number of participants were examined in these trials (354 (type 1 diabetes) for EUCLID, 1421 (type 1) and 1905 (type 2) for DIRECT, and 285 (type 1) for RASS, resp.), and the results from all three studies provided strong evidence that RAS inhibition delays the onset or prevents the development of human DR symptom. However, these treatments were not universally beneficial. For example, in DIRECT, ARBs were not effective with respect to primary endpoints and had differing effects regarding secondary endpoints in different patient groups (type I or type II diabetes) $[24,25]$.

Clues for why RAS inhibition is effective for treating DR have come from animal studies. Streptozotocin (STZ) injections in rodents induce leukocyte stasis, blood vessel hyperpermeability, and formation of acellular capillaries. Importantly, ERG recordings are attenuated in rodents after STZ injections before vascular phenotypes are observed, indicating that neuronal dysfunction precedes neovascularization in diabetic models $[9,135]$. Apoptosis of retinal neurons is also observed in later stage [136]. The administration of ACEI [137-140], ARB [10,13,14, 141], or PRRB [142] has been shown to rescue the vascular phenotypes of STZ-induced diabetic retinas. To generate another and more severe model of DR, Ren-2 transgenic rats (that have severe hypertension due to genetic knock-in of a mouse ren-2 renin gene [143]) can be injected with STZ. In these rats advanced vascular phenotypes are observed (including abnormal endothelial proliferation). Even in this model ACEI [144] or ARB [19, $145,146]$ administration served as effective treatments. RAS inhibitors probably function by suppressing inflammatory cascades [10, 14] and by preventing oxidative stress [147] by limiting $\mathrm{NF} \kappa \mathrm{B}$ and $\mathrm{NAD}(\mathrm{P}) \mathrm{H}$ activation. RAS inhibitors may also function to directly inhibit glucose accumulation into retinal cells by modulating GLUT-1 (glucose transporter 1) expression [148]. Furthermore, ARB was reported to influence the expression of glyoxalase I, a key regulator of AGEs [11]. Lastly, even though AT1R and AT2R are considered to have opposing functions AT2R inhibition may also effectively treat DR by suppressing VEGF and angiopoietin-2 expression levels in experimental retinopathies [33, 149].

4.4. Age-Related Macular Degeneration (AMD). AMD is one of the leading causes of blindness especially in western countries. The greatest risk factors are aging and smoking [1], and the central phenotypes are choroidal neovascularization (CNV; wet AMD) and atrophy of photoreceptors and RPE cells (dry AMD). While no cure exists for dry AMD, wet AMD is currently treated with VEGF inhibitors $[112,113]$. Inflammation exacerbates the wet AMD phenotype since infiltrating macrophages promote CNV formation [150-152]. Experimental CNV can be induced using laser coagulation to mechanically disrupt Bruch's membrane. The size of the laser-induced lesions after treatment with ACEI [153], ARB [16], and PRRB [154] is significantly reduced. Furthermore, AT1R-deficient mice are resistant to laser-induced CNV [154]. RAS inhibition may protect against CNV formation by inhibiting RAS activity and suppressing ERK signaling (directly with (pro)renin receptor-mediated intracellular signaling) $[154]$.

RPE cells are positioned between the choroidal vasculature and photoreceptors and have function to maintain the visual (retinoid) cycle and to form a tight seal that prevents choroidal vessel invasion. Angiotensin II signaling in RPE cells increases abnormal production [155-157] and excessive turnover [158] of ECM via MMP (matrix metalloproteinase)-2 and - 14 thereby weakening the seal that prevent choroidal EC invasion. These studies suggest that RAS inhibition may be an effective treatment for AMD as well as DR.

4.5. Glaucoma. Glaucoma is another age-related and high incidence ocular disease [2]. The feature of this disease is neurodegenerative of RGCs, but it can be caused by heterogeneous and complex mechanisms. One direct mechanism to induce RGC death is to increase the intraocular pressure (IOP). Studies devoted to developing new methods of controlling IOP are critical and ongoing. However, a subpopulation of glaucoma patients have normal IOP (normal tension glaucoma, NTG). This complicates the development of effective therapies since both forms are induced by seemingly separate mechanisms. Some RAS components including angiotensin II receptors are expressed in CB cells [90, 159, 160] that secrete aqueous humor and regulate IOP. Like other antihypertensive drugs such as calcium channel blockers, ACEI or ARB decreases IOP in humans and other primates [161-165] although IOP is considered to be regulated independently of systemic blood pressure. In an experimental model of high IOP and glaucoma, ARB treatments effectively suppress RGC death [23]. These findings suggest that RAS inhibition may be effective for treating glaucoma patients with high IOP.

\section{RAS Inhibition Protects Brain and Retinal Neurons}

Angiotensin II receptors are expressed inside and outside of the $\mathrm{BBB}[75,76,79-81]$ and the $\mathrm{BRB}[8,92,99,100]$ indicating that both circulating and tissue RAS exist in the CNS, 
and if dysregulated, could elicit pathological effects. Indeed, RAS inhibition can attenuate the degree of inflammation in the brain and the eye $[166,167]$. Inhibiting RAS can prevent experimental brain injuries induced by middle cerebral artery occlusion $[168,169]$ by suppressing vascular inflammation [170], including BBB breakdown [171], and/or regulating neural apoptosis directly [169]. Interestingly, AT2R is more highly expressed in developing neuronal tissues in vivo than in adult tissues [172] and AT2R stimulation promotes axonal regeneration of optic nerve [173] and minimizes formation of ischemia-induced cerebral lesions [174]. This suggests that ARB, which not only blocks AT1R but also causes angiotensin II to bind AT2R [175], may be an ideal drug for treating inflammatory diseases in the CNS. Inhibition of RAS may also prevent stress-induced behaviors including anxiety, depression, and panic by suppressing the release of corticotrophin-releasing factor [176-178]. Furthermore, recent studies suggest that brain RAS may potentiate Alzheimer's disease progression by stimulating the production of beta amyloid [179-182].

Retinal dysfunction as detected in ERG recordings can be observed in early diabetic animal models and in humans before vascular changes and neural cell loss are observed [135]. Amazingly, these deficits can be prevented by inhibiting RAS $[9,183,184]$. We have reported that ARB prevents retinal dysfunction (e.g., decrease of amplitude and an extension of the implicit time of ERG) in EIU [8] and in STZinduced early diabetic retinas [9]. Furthermore, in these inflamed retinas, we determined that angiotensin II prompted the degradation of the presynaptic protein synaptophysin through the ubiquitin proteasome system (UPS) $[8,9]$. UPSmediated degradation of rhodopsin (part of the light-responsive complex in photoreceptors) can also be observed in EIU via STAT3 activation (which operates downstream of AT1R) $[8,185]$. Additionally, STAT3 signaling serves as a negative regulator of rhodopsin in differentiating photoreceptors during retinal development $[186,187]$. Thus, regulating angiotensin-II-induced protein degradation could serve as an important neuroprotective measure [188] (Figure 3).

Another target of inflammation is reactive glia including microglia, astrocytes, and Muller glia. Activated glia cause gliosis and alter proper neuronal morphology. Microglia are resident CNS myeloid-derived cells and mediate critical immune and inflammatory responses. AT1R signaling induces activation of microglia via NF $\kappa$ B and AP- $1[189,190]$. GFAP (glial fibrillary acidic protein) is a differential and reactive marker of astrocyte and Muller glia, respectively, and its transcription is regulated by STAT3 activation [191]. The activation of astrocytes and Muller glia in experimental retinopathy can be prevented by ARB [8, 192] (Figure 3), although it is important to consider that the contributions of reactive glia can be context dependent [193].

IOP-independent RGC apoptosis can be observed in STZ-induced diabetes [136], after ischemia/reperfusion [194], after optic nerve crush [195], and after intraocular NMDA ( $N$-methyl-D-aspartic acid) injections [196] in animal models. RGC loss in diabetic hypertensive models can be prevented by ARB which restores oxidative redox and mitochondrial functions [22]. ACEI or ARB also prevents RGC apoptosis in ischemia/reperfusion models by suppressing toxic oxidative stress [21]. ARB can also rescue dying amacrine cells in OIR [20]. Polymorphisms of RAS pathway genes are reported to be associated with brain infarction or its early lesion [197-199] and AT2R gene polymorphisms are reported to be associated with the risk of NTG [107]. These findings may indicate that RAS inhibitors may directly protect retinal neurons from apoptosis and further suggest that RAS inhibition may be useful for therapeutic treatments of IOP-independent glaucoma.

\section{Conclusion}

RAS, which has been classically known as blood pressure regulator, is becoming widely recognized as a proinflammatory mediator. Many age-related ocular diseases may be caused or exacerbated by chronic inflammation. Cells in the eye are responsive to circulating and tissue RAS and increasing evidence indicates that RAS inhibition may prevent various ocular diseases including uveitis, AMD, and glaucoma. Based on the findings from multiple clinical trials, RAS inhibitors are effective therapeutic agents for treating DR although the results of these studies must be examined critically since the inhibitors were not universally beneficial. Other groups including our own have shown that RAS inhibitors protect neurons from oxidative stress and apoptosis by preventing posttranslational ubiquitination of proteins critical for retinal functions. Although not mentioned previously in this paper, another new and exciting RAS inhibitor, aliskiren (a direct renin inhibitor), has been developed. It may actually mediate more robust vascular protection than either ACEI or ARB [200]. Therefore, work is underway to characterize existing RAS inhibitors and to develop novel inhibitors since they hold great promise for attenuating chronic inflammation and for treating multiple ocular and nonocular diseases.

\section{Abbreviations List (In Order of Their Appearance)}

RAS: Renin-angiotensin system

DR: Diabetic retinopathy

AMD: Age-related macular degeneration

CNS: Central nervous system

RPE: Retinal pigment epithelium

ARB: Angiotensin II type 1 receptor blocker

ACE: Angiotensin-converting enzyme

EC: Vascular endothelial cell

VSMC: Vascular smooth muscle cell

AT1R: Angiotensin II type 1 receptor

IP3: Inositol-1,4,5-triphosphate

PLC: Phospholipase C

ECM: Extracellular matrix

JAK: Janus kinase

STAT: Signal transducer and activator of transcription

ERK: Extracellular-signal-regulated kinase

MAPK: Mitogen-activated protein kinase 
$\mathrm{NAD}(\mathrm{P}) \mathrm{H}$ : Nicotinamide adenine dinucleotide phosphate

NF $\kappa$ B: Nuclear factor kappa-light-chain-enhancer of activated B cells

AP-1: $\quad$ Activator protein 1

EGFR: Epidermal growth factor receptor

TGF $\beta$ : Transforming growth factor beta

PAI-1: Plasminogen activator inhibitor-1

MCP-1: Monocyte chemotactic protein-1

ACEI: ACE inhibitor

BBB: Blood-brain barrier

CB: Ciliary body

RGC: $\quad$ Retinal ganglion cell

BRB: Blood-retina barrier

ERG: Electroretinogram

EIU: $\quad$ Endotoxin-induced uveitis

LPS: Lipopolysaccharide

ICAM-1: Intercellular adhesion molecule 1

IL-6: $\quad$ Interleukin 6

IFN- $\gamma$ : Interferon-gamma

EAU: Experimental autoimmune uveoretinitis

IRBP: Interphotoreceptor retinoid-binding protein

PRRB: (Pro)renin receptor blocker

VEGF: Vascular endothelial growth factor

VEGFR: VEGF receptor

OIR: Oxygen-induced retinopathy

AGE: $\quad$ Advanced glycation end-product

PDR: $\quad$ Proliferative diabetic retinopathy

DME: $\quad$ Diabetic macular edema

EUCLID: EURODIAB Controlled Trial of Lisinopril in Insulin-Dependent Diabetes

DIRECT Diabetic Retinopathy Candesartan Trial

RASS: Renin-Angiotensin System Study

STZ: Streptozotosin

GLUT-1: Glucose transporter 1

CNV: Choroidal neovascularization

MMP: $\quad$ Matrix metalloproteinase

IOP: Intraocular pressure

NTG: Normal tension glaucoma

GFAP: Glial fibrillary acidic protein

NMDA: N-methyl-D-aspartic acid.

\section{Acknowledgments}

T. Kurihara is supported by a fellowship from the Manpei Suzuki Diabetes Foundation and The Japan Society for the Promotion of Science (JSPS) Postdoctoral Fellowships for Research Abroad. The authors thank Drs. Martin Friedlander, Peter D. Westenskow, and Lea Scheppke for the critical reading of the paper.

\section{References}

[1] R. Klein, B. E. K. Klein, and K. L. P. Linton, "Prevalence of age-related maculopathy: the Beaver Dam Eye study," Ophthalmology, vol. 99, no. 6, pp. 933-943, 1992.

[2] J. M. Tielsch, A. Sommer, J. Katz, R. M. Royall, H. A. Quigley, and J. Javitt, "Racial variations in the prevalence of primary open-angle glaucoma: the Baltimore eye survey," Journal of the American Medical Association, vol. 266, no. 3, pp. 369374, 1991.

[3] M. D. Davis, M. R. Fisher, R. E. Gangnon et al., "Risk factors for high-risk proliferative diabetic retinopathy and severe visual loss: early treatment diabetic retinopathy study report 18," Investigative Ophthalmology and Visual Science, vol. 39, no. 2, pp. 233-252, 1998.

[4] M. C. Haigis and B. A. Yankner, "The Aging Stress Response," Molecular Cell, vol. 40, no. 2, pp. 333-344, 2010.

[5] C. K. Glass, K. Saijo, B. Winner, M. C. Marchetto, and F. H. Gage, "Mechanisms Underlying Inflammation in Neurodegeneration," Cell, vol. 140, no. 6, pp. 918-934, 2010.

[6] R. S. Balaban, S. Nemoto, and T. Finkel, "Mitochondria, oxidants, and aging," Cell, vol. 120, no. 4, pp. 483-495, 2005.

[7] M. Salzet, L. Deloffre, C. Breton, D. Vieau, and L. Schoofs, "The angiotensin system elements in invertebrates," Brain Research Reviews, vol. 36, no. 1, pp. 35-45, 2001.

[8] T. Kurihara, Y. Ozawa, K. Shinoda et al., "Neuroprotective effects of angiotensin II type 1 receptor (AT1R) blocker, telmisartan, via modulating AT1R and AT2R signaling in retinal inflammation," Investigative Ophthalmology and Visual Science, vol. 47, no. 12, pp. 5545-5552, 2006.

[9] T. Kurihara, Y. Ozawa, N. Nagai et al., "Angiotensin II type 1 receptor signaling contributes to synaptophysin degradation and neuronal dysfunction in the diabetic retina," Diabetes, vol. 57, no. 8, pp. 2191-2198, 2008.

[10] P. Chen, G. M. Scicli, M. Guo et al., "Role of angiotensin II in retinal leukostasis in the diabetic rat," Experimental Eye Research, vol. 83, no. 5, pp. 1041-1051, 2006.

[11] A. G. Miller, G. Tan, K. J. Binger et al., "Candesartan attenuates diabetic retinal vascular pathology by restoring glyoxalase-I function," Diabetes, vol. 59, no. 12, pp. 3208-3215, 2010.

[12] A. Miyazaki, N. Kitaichi, K. Ohgami et al., "Anti-inflammatory effect of angiotensin type 1 receptor antagonist on endotoxin-induced uveitis in rats," Graefe's Archive for Clinical and Experimental Ophthalmology, vol. 246, no. 5, pp. 747757, 2008.

[13] F. Mori, T. Hikichi, T. Nagaoka, J. Takahashi, N. Kitaya, and A. Yoshida, "Inhibitory effect of losartan, an AT1 angiotensin II receptor antagonist, on increased leucocyte entrapment in retinal microcirculation of diabetic rats," British Journal of Ophthalmology, vol. 86, no. 10, pp. 1172-1174, 2002.

[14] N. Nagai, K. Izumi-Nagai, Y. Oike et al., "Suppression of diabetes-induced retinal inflammation by blocking the angiotensin II type 1 receptor or its downstream nuclear factor- $\kappa \mathrm{B}$ pathway," Investigative Ophthalmology and Visual Science, vol. 48, no. 9, pp. 4342-4350, 2007.

[15] N. Nagai, K. Noda, T. Urano et al., "Selective suppression of pathologic, but not physiologic, retinal neovascularization by blocking the angiotensin II type 1 receptor," Investigative Ophthalmology and Visual Science, vol. 46, no. 3, pp. 1078$1084,2005$.

[16] N. Nagai, Y. Oike, K. Izumi-Nagai et al., "Angiotensin II type 1 receptor-mediated inflammation is required for choroidal neovascularization," Arteriosclerosis, Thrombosis, and Vascular Biology, vol. 26, no. 10, pp. 2252-2259, 2006.

[17] N. Nagai, Y. Oike, K. Noda et al., "Suppression of ocular inflammation in endotoxin-induced uveitis by blocking the angiotensin II type 1 receptor," Investigative Ophthalmology and Visual Science, vol. 46, no. 8, pp. 2925-2931, 2005.

[18] Y. Okunuki, Y. Usui, N. Nagai et al., "Suppression of experimental autoimmune uveitis by angiotensin II type 1 
receptor blocker telmisartan," Investigative Ophthalmology and Visual Science, vol. 50, no. 5, pp. 2255-2261, 2009.

[19] J. L. Wilkinson-Berka, G. Tan, K. Jaworski, and S. Ninkovic, "Valsartan but not Atenolol Improves Vascular Pathology in Diabetic Ren-2 Rat Retina," American Journal of Hypertension, vol. 20, no. 4, pp. 423-430, 2007.

[20] L. E. Downie, K. M. Hatzopoulos, M. J. Pianta et al., "Angiotensin type-1 receptor inhibition is neuroprotective to amacrine cells in a rat model of retinopathy of prematurity," Journal of Comparative Neurology, vol. 518, no. 1, pp. 41-63, 2010.

[21] K. Fukuda, K. Hirooka, M. Mizote, T. Nakamura, T. Itano, and F. Shiraga, "Neuroprotection against retinal ischemiareperfusion injury by blocking the angiotensin II type 1 receptor," Investigative Ophthalmology \& Visual Science, vol. 51, no. 7, pp. 3629-3638, 2010.

[22] K. C. Silva, M. A. B. Rosales, S. K. Biswas, J. B. L. De Faria, and J. M. L. De Faria, "Diabetic retinal neurodegeneration is associated with mitochondrial oxidative stress and is improved by an angiotensin receptor blocker in a model combining hypertension and diabetes," Diabetes, vol. 58, no. 6 , pp. 1382-1390, 2009.

[23] H. Yang, K. Hirooka, K. Fukuda, and F. Shiraga, "Neuroprotective effects of angiotensin II type 1 receptor blocker in a rat model of chronic glaucoma," Investigative Ophthalmology \& Visual Science, vol. 50, no. 12, pp. 5800-5804, 2009.

[24] N. Chaturvedi, M. Porta, R. Klein et al., "Effect of candesartan on prevention (DIRECT-Prevent 1 ) and progression (DIRECT-Protect 1) of retinopathy in type 1 diabetes: randomised, placebo-controlled trials," The Lancet, vol. 372, no. 9647, pp. 1394-1402, 2008.

[25] A. K. Sjolie, R. Klein, M. Porta et al., "Effect of candesartan on progression and regression of retinopathy in type 2 diabetes (DIRECT-Protect 2): a randomised placebo-controlled trial," The Lancet, vol. 372, no. 9647, pp. 1385-1393, 2008.

[26] M. Mauer, B. Zinman, R. Gardiner et al., "Renal and retinal effects of enalapril and losartan in type 1 diabetes," New England Journal of Medicine, vol. 361, no. 1, pp. 40-51, 2009.

[27] H. Goldblatt, J. Lynch, R. F. Hanzal, and W. W. Summerville, "Studies on experimental hypertension : I. The production of persistent elevation of systolic blood pressure by means of renal ischemia," The Journal of Experimental Medicine, vol. 59, no. 3, pp. 347-379, 1934.

[28] J. C. Fasciolo, B. A. Houssay, and A. C. Taquini, "The blood-pressure raising secretion of the ischaemic kidney," The Journal of Physiology, vol. 94, no. 3, pp. 281-293, 1938.

[29] I. H. Page, "On the nature of the pressor action of renin," The Journal of Experimental Medicine, vol. 70, no. 5, pp. 521-542, 1939.

[30] E. Braun-Menendez and I. H. Page, "Suggested revision of nomenclature-angiotensin," Science, vol. 127, no. 3292, p. $242,1958$.

[31] L. T. Skeggs Jr, J. R. Kahn, and N. P. Shumway, "The preparation and function of the hypertensin-converting enzyme," The Journal of Experimental Medicine, vol. 103, no. 3, pp. 295-299, 1956.

[32] S. Y. Lin and T. L. Goodfriend, "Angiotensin receptors," The American journal of physiology, vol. 218, no. 5, pp. 1319-1328, 1970.

[33] S. Sarlos, B. Rizkalla, C. J. Moravski, Z. Cao, M. E. Cooper, and J. L. Wilkinson-Berka, "Retinal angiogenesis is mediated by an interaction between the angiotensin type 2 receptor, VEGF, and angiopoietin," American Journal of Pathology, vol. 163, no. 3, pp. 879-887, 2003.
[34] Q. Xue, C. Dasgupta, M. Chen, and L. Zhang, "Foetal hypoxia increases cardiac $\mathrm{AT}_{2} \mathrm{R}$ expression and subsequent vulnerability to adult ischaemic injury," Cardiovascular Research, vol. 89, no. 2, pp. 300-308, 2011.

[35] K. Sasaki, Y. Yamano, S. Bardhan et al., "Cloning and expression of a complementary DNA encoding a bovine adrenal angiotensin II type-1 receptor," Nature, vol. 351, no. 6323, pp. 230-233, 1991.

[36] T. J. Murphy, R. W. Alexander, K. K. Griendling, M. S. Runge, and K. E. Bernstein, "Isolation of a cDNA encoding the vascular type-1 angiotensin II receptor," Nature, vol. 351, no. 6323, pp. 233-236, 1991.

[37] M. Ushio-Fukai, K. K. Griendling, M. Akers, P. R. Lyons, and R. W. Alexander, "Temporal dispersion of activation of phospholipase $\mathrm{C}-\beta 1$ and $-\gamma$ isoforms by angiotensin II in vascular smooth muscle cells. Role of $\alpha \mathrm{q} / 11, \alpha 12$, and $\beta \gamma \mathrm{G}$ protein subunits," The Journal of Biological Chemistry, vol. 273, no. 31, pp. 19772-19777, 1998.

[38] J. M. Anderson, M. A. Gimbrone, and R. W. Alexander, "Angiotensin II stimulates phosphorylation of the myosin light chain in cultured vascular smooth muscle cells," Journal of Biological Chemistry, vol. 256, no. 10, pp. 4693-4696, 1981.

[39] D. E. Dostal, T. Murahashi, and M. J. Peach, "Regulation of cytosolic calcium by angiotensins in vascular smooth muscle," Hypertension, vol. 15, no. 6, pp. 815-822, 1990.

[40] F. Soubrier, F. Alhenc-Gelas, C. Hubert et al., "Two putative active centers in human angiotensin I-converting enzyme revealed by molecular cloning," Proceedings of the National Academy of Sciences of the United States of America, vol. 85, no. 24, pp. 9386-9390, 1988.

[41] L. J. Dell'Italia, Q. C. Meng, E. Balcells et al., "Compartmentalization of angiotensin II generation in the dog heart: evidence for independent mechanisms in intravascular and interstitial spaces," Journal of Clinical Investigation, vol. 100, no. 2, pp. 253-258, 1997.

[42] H. M. Kimbrough, E. D. Vaughan, R. M. Carey, and C. R. Ayers, "Effect of intrarenal angiotensin II blockade on renal function in conscious dogs," Circulation Research, vol. 40, no. 2, pp. 174-178, 1977.

[43] J. W. Ryan, "Renin-like enzyme in the adrenal gland," Science, vol. 158, no. 3808, pp. 1589-1590, 1967.

[44] D. Ganten, J. L. Minnich, P. Granger et al., "Angiotensin-forming enzyme in brain tissue," Science, vol. 173, no. 3991, pp. 64-65, 1971.

[45] A. Ichihara, M. Hayashi, Y. Kaneshiro et al., "Inhibition of diabetic nephropathy by a decoy peptide corresponding to the "handle" region for nonproteolytic activation of prorenin," Journal of Clinical Investigation, vol. 114, no. 8, pp. 1128-1135, 2004.

[46] G. Nguyen, F. Delarue, C. Burcklé, L. Bouzhir, T. Giller, and J. D. Sraer, "Pivotal role of the renin/prorenin receptor in angiotensin II production and cellular responses to renin," Journal of Clinical Investigation, vol. 109, no. 11, pp. 1417-1427, 2002.

[47] C. M. Cruciat, B. Ohkawara, S. P. Acebron et al., "Requirement of prorenin receptor and vacuolar $\mathrm{H}+$-ATPase-mediated acidification for Wnt signaling," Science, vol. 327, no. 5964, pp. 459-463, 2010.

[48] M. B. Marrero, B. Schieffer, W. G. Paxton et al., "Direct stimulation of Jak/STAT pathway by the anglotensin II AT1 receptor," Nature, vol. 375, no. 6528, pp. 247-250, 1995.

[49] B. Schieffer, M. Luchtefeld, S. Braun, A. Hilfiker, D. HilfikerKleiner, and H. Drexler, "Role of $\mathrm{NAD}(\mathrm{P}) \mathrm{H}$ oxidase in angiotensin II-induced JAK/STAT signaling and cytokine 
induction," Circulation Research, vol. 87, no. 12, pp. 11951201, 2000.

[50] S. Kim, Y. Izumi, M. Yano et al., "Angiotensin blockade inhibits activation of mitogen-activated protein kinases in rat balloon-injured artery," Circulation, vol. 97, no. 17, pp. 17311737, 1998.

[51] D. F. Liao, J. L. Duff, G. Daum, S. L. Pelech, and B. C. Berk, "Angiotensin II stimulates MAP kinase kinase kinase activity in vascular smooth muscle cells: role of raf," Circulation Research, vol. 79, no. 5, pp. 1007-1014, 1996.

[52] D. F. Liao, B. Monia, N. Dean, and B. C. Berk, "Protein kinase $\mathrm{C}-\zeta$ mediates angiotensin II activation of ERK1/2 in vascular smooth muscle cells," Journal of Biological Chemistry, vol. 272, no. 10, pp. 6146-6150, 1997.

[53] M. Nishida, S. Tanabe, Y. Maruyama et al., " $\mathrm{G} \alpha 12 / 13$ - and reactive oxygen species-dependent activation of c-Jun NH2terminal kinase and p38 mitogen-activated protein kinase by angiotensin receptor stimulation in rat neonatal cardiomyocytes," Journal of Biological Chemistry, vol. 280, no. 18, pp. 18434-18441, 2005.

[54] S. Rajagopalan, S. Kurz, T. Münzel et al., "Angiotensin II-mediated hypertension in the rat increases vascular superoxide production via membrane NADH/NADPH oxidase activation: contribution to alterations of vasomotor tone," Journal of Clinical Investigation, vol. 97, no. 8, pp. 1916-1923, 1996.

[55] R. M. Touyz, X. Chen, F. Tabet et al., "Expression of a functionally active gp91phox-containing neutrophil-type $\mathrm{NAD}(\mathrm{P}) \mathrm{H}$ oxidase in smooth muscle cells from human resistance arteries: regulation by angiotensin II," Circulation Research, vol. 90, no. 11, pp. 1205-1213, 2002.

[56] K. K. Griendling, C. A. Minieri, J. D. Ollerenshaw, and R. W. Alexander, "Angiotensin II stimulates NADH and NADPH oxidase activity in cultured vascular smooth muscle cells," Circulation Research, vol. 74, no. 6, pp. 1141-1148, 1994.

[57] P. N. Seshiah, D. S. Weber, P. Rocic, L. Valppu, Y. Taniyama, and K. K. Griendling, "Angiotensin II stimulation of $\mathrm{NAD}(\mathrm{P}) \mathrm{H}$ oxidase activity: upstream mediators," Circulation Research, vol. 91, no. 5, pp. 406-413, 2002.

[58] Y. Moriguchi, H. Matsubara, Y. Mori et al., "Angiotensin IIinduced transactivation of epidermal growth factor receptor regulates fibronectin and transforming growth factor- $\beta$ synthesis via transcriptional and posttranscriptional mechanisms," Circulation Research, vol. 84, no. 9, pp. 1073-1084, 1999.

[59] S. Kagiyama, S. Eguchi, G. D. Frank, T. Inagami, Y. C. Zhang, and M. I. Phillips, "Angiotensin II-induced cardiac hypertrophy and hypertension are attenuated by epidermal growth factor receptor antisense," Circulation, vol. 106, no. 8, pp. 909-912, 2002.

[60] D. N. Muller, R. Dechend, E. M. A. Mervaala et al., "NF- $\kappa$ B inhibition ameliorates angiotensin II-induced inflammatory damage in rats," Hypertension, vol. 35, no. 1, pp. 193-201, 2000.

[61] A. Fiebeler, F. Schmidt, D. N. Müller et al., "Mineralocorticoid receptor affects AP- 1 and nuclear factor- $\kappa \mathrm{B}$ activation in angiotensin II-induced cardiac injury," Hypertension, vol. 37, no. 2, pp. 787-793, 2001.

[62] M. Hernández-Presa, C. Bustos, M. Ortego et al., "Angiotensin-converting enzyme inhibition prevents arterial nuclear factor- $\kappa \mathrm{B}$ activation, monocyte chemoattractant protein-1 expression, and macrophage infiltration in a rabbit model of early accelerated atherosclerosis," Circulation, vol. 95, no. 6, pp. 1532-1541, 1997.
[63] S. Kudoh, I. Komuro, T. Mizuno et al., "Angiotensin II stimulates c-jun NH2-terminal kinase in cultured cardiac myocytes of neonatal rats," Circulation Research, vol. 80, no. 1, pp. 139146, 1997.

[64] P. L. Puri, M. L. Avantaggiati, V. L. Burgio et al., "Reactive oxygen intermediates mediate angiotensin II-induced cJun. $\mathrm{c}$-Fos heterodimer DNA binding activity and proliferative hypertrophic responses in myogenic cells," Journal of Biological Chemistry, vol. 270, no. 38, pp. 22129-22134, 1995.

[65] D. E. Vaughan, S. A. Lazos, and K. Tong, "Angiotensin II regulates the expression of plasminogen activator inhibitor-1 in cultured endothelial cells. A potential link between the renin-angiotensin system and thrombosis," Journal of Clinical Investigation, vol. 95, no. 3, pp. 995-1001, 1995.

[66] A. Daugherty, M. W. Manning, and L. A. Cassis, "Angiotensin II promotes atherosclerotic lesions and aneurysms in apolipoprotein E-deficient mice," Journal of Clinical Investigation, vol. 105, no. 11, pp. 1605-1612, 2000.

[67] M. A. Ondetti, B. Rubin, and D. W. Cushman, "Design of specific inhibitors of angiotensin converting enzyme: new class of orally active antihypertensive agents," Science, vol. 196, no. 4288, pp. 441-444, 1977.

[68] P. B. M. W. M. Timmermans, D. J. Carini, A. T. Chiu et al., "Angiotensin II receptor antagonists: from discovery to antihypertensive drugs," Hypertension, vol. 18, no. 5, pp. I-136I-142, 1991.

[69] P. C. Wong, W. A. Price, A. T. Chiu et al., "Nonpeptide an0 giotensin II receptor antagonists. Studies with EXP9270 and DuP 753," Hypertension, vol. 15, no. 6, pp. 823-834, 1990.

[70] D. R. Green, L. Galluzzi, and G. Kroemer, "Mitochondria and the autophagy-inflammation-cell death axis in organismal aging," Science, vol. 333, no. 6046, pp. 1109-1112, 2011.

[71] G. Baiardi, C. Bregonzio, M. Jezova, I. Armando, and J. M. Saavedra, "Angiotensin II AT1 receptor blockade prolongs the lifespan of spontaneously hypertensive rats and reduces stress-induced release of catecholamines, glucocorticoids, and vasopressin," Annals of the New York Academy of Sciences, vol. 1018, pp. 131-136, 2004.

[72] W. Linz, H. Heitsch, B. A. Schölkens, and G. Wiemer, "Longterm angiotensin II type 1 receptor blockade with fonsartan doubles lifespan of hypertensive rats," Hypertension, vol. 35, no. 4, pp. 908-913, 2000.

[73] W. Linz, T. Jessen, R. H. A. Becker, B. A. Schölkens, and G. Wiemer, "Long-term ACE inhibition doubles lifespan of hypertensive rats," Circulation, vol. 96, no. 9, pp. 3164-3172, 1997.

[74] A. Benigni, D. Corna, C. Zoja et al., "Disruption of the Ang II type 1 receptor promotes longevity in mice," Journal of Clinical Investigation, vol. 119, no. 3, pp. 524-530, 2009.

[75] F. A. Mendelsohn, R. Quirion, J. M. Saavedra, G. Aguilera, and K. J. Catt, "Autoradiographic localization of angiotensin II receptors in rat brain," Proceedings of the National Academy of Sciences of the United States of America, vol. 81, no. 5, pp. 1575-1579, 1984.

[76] J. M. Saavedra, F. M.A. Correa, and L. M. Plunkett, "Binding of angiotensin and atrial natriuretic peptide in brain of hypertensive rats," Nature, vol. 320, no. 6064, pp. 758-760, 1986.

[77] J. Buggy, A. E. Fisher, and W. E. Hoffman, "Ventricular obstruction: effect on drinking induced by intracranial injection of angiotensin," Science, vol. 190, no. 4209, pp. 72-74, 1975. 
[78] M. Van Houten, E. L. Schiffrin, and J. F. E. Mann, "Radioautographic localization of specific binding sites for bloodborne angiotensin II in the rat brain," Brain Research, vol. 186, no. 2, pp. 480-485, 1980.

[79] R. Castren and J. M. Saavedra, "Angiotensin II receptors in paraventricular nucleus, subfornical organ, and pituitary gland of hypophysectomized, adrenalectomized, and vasopressin-deficient rats," Proceedings of the National Academy of Sciences of the United States of America, vol. 86, no. 2, pp. 725-729, 1989.

[80] C. Chevillard and J. M. Saavedra, "High angiotensin-converting enzyme activity in the neurohypophysis of Brattleboro rats," Science, vol. 216, no. 4546, pp. 646-647, 1982.

[81] S. Landas, M. I. Phillips, J. F. Stamler, and M. K. Raizada, "Visualization of specific angiotensin II binding sites in the brain by fluorescent microscopy," Science, vol. 210, no. 4471, pp. 791-793, 1980.

[82] M. C. Zimmerman, E. Lazartigues, J. A. Lang et al., "Superoxide mediates the actions of angiotensin II in the central nervous system," Circulation Research, vol. 91, no. 11, pp. 10381045, 2002.

[83] A. H. J. Danser, M. A. Van Den Dorpel, J. Deinum et al., "Renin, prorenin, and immunoreactive renin in vitreous fluid from eyes with and without diabetic retinopathy," Journal of Clinical Endocrinology and Metabolism, vol. 68, no. 1, pp. 160-167, 1989.

[84] J. Deinum, F. H. M. Derkx, A. H. J. Danser, and M. A. D. H. Schalekamp, "Identification and quantification of renin and prorenin in the bovine eye," Endocrinology, vol. 126, no. 3, pp. 1673-1682, 1990.

[85] S. J. Sramek, I. H. L. Wallow, R. P. Day, and E. N. Ehrlich, "Ocular renin-angiotensin: immunohistochemical evidence for the presence of prorenin in eye tissue," Investigative Ophthalmology and Visual Science, vol. 29, no. 11, pp. 1749-1752, 1988.

[86] J. L. Berka, A. J. Stubbs, D. Z. M. Wang et al., "Renin-containing muller cells of the retina display endocrine features," Investigative Ophthalmology and Visual Science, vol. 36, no. 7, pp. 1450-1458, 1995.

[87] C. R. Brandt, A. M. Pumfery, B. Micales et al., "Renin mRNA is synthesized locally in rat ocular tissues," Current Eye Research, vol. 13, no. 10, pp. 755-763, 1994.

[88] S. Satofuka, A. Ichihara, N. Nagai et al., "Suppression of ocular inflammation in endotoxin-induced uveitis by inhibiting nonproteolytic activation of prorenin," Investigative Ophthalmology \& Visual Science, vol. 47, no. 6, pp. 26862692, 2006.

[89] J. L. Wilkinson-Berka, R. Heine, G. Tan et al., "RILLKKMPSV Influences the vasculature, neurons and glia, and (Pro)renin receptor expression in the Retina," Hypertension, vol. 55, no. 6, pp. 1454-1460, 2010.

[90] S. J. Sramek, I. H. L. Wallow, D. A. Tewksbury, C. R. Brandt, and G. L. Poulsen, "An ocular renin-angiotensin system: immunohistochemistry of angiotensinogen," Investigative Ophthalmology and Visual Science, vol. 33, no. 5, pp. 16271632, 1992.

[91] C. Gerhardinger, M. B. Costa, M. C. Coulombe, I. Toth, T. Hoehn, and P. Grosu, "Expression of acute-phase response proteins in retinal Muller cells in diabetes," Investigative Ophthalmology and Visual Science, vol. 46, no. 1, pp. 349-357, 2005.

[92] J. Wagner, A. H. J. Danser, F. H. M. Derkx et al., "Demonstration of renin mRNA, angiotensinogen mRNA, and angiotensin converting enzyme mRNA expression in the human eye: evidence for an intraocular renin-angiotensin system," British Journal of Ophthalmology, vol. 80, no. 2, pp. 159-163, 1996.

[93] R. Igic and V. Kojovic, "Angiotensin I converting enzyme (kininase II) in ocular tissues," Experimental Eye Research, vol. 30, no. 3, pp. 299-303, 1980.

[94] G. Ferrari-Dileo, J. W. Ryan, E. J. Rockwood, E. B. Davis, and D. R. Anderson, "Angiotensin-converting enzyme in bovine, feline, and human ocular tissues," Investigative Ophthalmology and Visual Science, vol. 29, no. 6, pp. 876-881, 1988.

[95] E. Savaskan, K. U. Löffler, F. Meier, F. Müller-Spahn, J. Flammer, and P. Meyer, "Immunohistochemical localization of angiotensin-converting enzyme, angiotensin II and AT1 receptor in human ocular tissues," Ophthalmic Research, vol. 36, no. 6, pp. 312-320, 2004.

[96] T. Kida, T. Ikeda, M. Nishimura et al., "Renin-angiotensin system in proliferative diabetic retinopathy and its gene expression in cultured human Müller cells," Japanese Journal of Ophthalmology, vol. 47, no. 1, pp. 36-41, 2003.

[97] A. H. J. Danser, F. H. M. Derkx, P. J. J. Admiraal, J. Deinum, P. T. V. M. De Jong, and M. A. D. H. Schalekamp, "Angiotensin levels in the eye," Investigative Ophthalmology and Visual Science, vol. 35, no. 3, pp. 1008-1018, 1994.

[98] K. H. Datum and E. Zrenner, "Angiotensin-like immunoreactive cells in the chicken retina," Experimental Eye Research, vol. 53, no. 2, pp. 157-165, 1991.

[99] P. Mallorga, R. W. Babilon, and M. F. Sugrue, "Angiotensin II receptors labelled with 125I-[Sar1,Ile8]-AII in albino rabbit ocular tissues," Current Eye Research, vol. 8, no. 8, pp. 841849, 1989.

[100] P. D. Senanayake, J. Drazba, K. Shadrach et al., "Angiotensin II and its receptor subtypes in the human retina," Investigative Ophthalmology and Visual Science, vol. 48, no. 7, pp. 3301-3311, 2007.

[101] C. Sun, H. Li, L. Leng, M. K. Raizada, R. Bucala, and C. Sumners, "Macrophage migration inhibitory factor: an intracellular inhibitor of angiotensin II-induced increases in neuronal activity," Journal of Neuroscience, vol. 24, no. 44, pp. 9944-9952, 2004.

[102] D. P. Li, S. R. Chen, and H. L. Pan, "Angiotensin II stimulates spinally projecting paraventricular neurons through presynaptic disinhibition," Journal of Neuroscience, vol. 23, no. 12, pp. 5041-5049, 2003.

[103] E. Guenther, S. Schmid, B. Hewig, and K. Kohler, "Twofold effect of angiotensin II on voltage-dependent calcium currents in rat retinal ganglion cells," Brain Research, vol. 718, no. 1-2, pp. 112-116, 1996.

[104] E. Demant, K. Nagahara, and G. Niemeyer, "Effects of changes in systemic blood pressure on the electroretinogram of the cat: evidence for retinal autoregulation," Investigative Ophthalmology and Visual Science, vol. 23, no. 5, pp. 683-687, 1982.

[105] P. C. Jacobi, H. Osswald, B. Jurklies, and E. Zrenner, "Neuromodulatory effects of the renin-angiotensin system on the cat electroretinogram," Investigative Ophthalmology and Visual Science, vol. 35, no. 3, pp. 973-980, 1994.

[106] B. Jurklies, A. Eckstein, P. Jacobi, K. Kohler, T. Risler, and E. Zrenner, "The renin-angiotensin system-a possible neuromodulator in the human retina?" German journal of ophthalmology, vol. 4, no. 3, pp. 144-150, 1995.

[107] K. Hashizume, Y. Mashima, T. Fumayama et al., "Genetic polymorphisms in the angiotensin II receptor gene and their association with open-angle glaucoma in a Japanese 
population," Investigative Ophthalmology and Visual Science, vol. 46, no. 6, pp. 1993-2001, 2005.

[108] Y.-P. Liu, T. Kuznetsova, L. Thijs et al., "Are retinal microvascular phenotypes associated with the $1675 \mathrm{G} / \mathrm{A}$ polymorphism in the angiotensin II Type-2 receptor gene," American Journal of Hypertension, vol. 24, no. 12, pp. 1300-1305, 2011.

[109] K. Yuki, Y. Ozawa, T. Yoshida et al., "Retinal ganglion cell loss in superoxide dismutase 1 deficiency," Investigative Ophthalmology of Visual Science, vol. 52, no. 7, pp. 4143-4150, 2011.

[110] Y. Imamura, S. Noda, K. Hashizume et al., "Drusen, choroidal neovascularization, and retinal pigment epithelium dysfunction in SOD1-deficient mice: a model of age-related macular degeneration," Proceedings of the National Academy of Sciences of the United States of America, vol. 103, no. 30, pp. 11282-11287, 2006.

[111] L. P. Aiello, R. L. Avery, P. G. Arrigg et al., "Vascular endothelial growth factor in ocular fluid of patients with diabetic retinopathy and other retinal disorders," New England Journal of Medicine, vol. 331, no. 22, pp. 1480-1487, 1994.

[112] E. S. Gragoudas, A. P. Adamis, E. T. Cunningham, M. Feinsod, and D. R. Guyer, "Pegaptanib for neovascular age-related macular degeneration," New England Journal of Medicine, vol. 351, no. 27, pp. 2805-2816, 2004.

[113] P. J. Rosenfeld, D. M. Brown, J. S. Heier et al., "Ranibizumab for neovascular age-related macular degeneration," New England Journal of Medicine, vol. 355, no. 14, pp. 1419-1431, 2006.

[114] S. Ishida, T. Usui, K. Yamashiro et al., "VEGF164 is proinflammatory in the diabetic retina," Investigative Ophthalmology and Visual Science, vol. 44, no. 5, pp. 2155-2162, 2003.

[115] S. Ishida, T. Usui, K. Yamashiro et al., "VEGF164-mediated inflammation is required for pathological, but not physiological, ischemia-induced retinal neovascularization," Journal of Experimental Medicine, vol. 198, no. 3, pp. 483-489, 2003.

[116] S. Ishida, K. Yamashiro, T. Usui et al., "Leukocytes mediate retinal vascular remodeling during development and vasoobliteration in disease," Nature Medicine, vol. 9, no. 6, pp. 781-788, 2003.

[117] A. Otani, H. Takagi, K. Suzuma, and Y. Honda, "Angiotensin II potentiates vascular endothelial growth factor-induced angiogenic activity in retinal microcapillary endothelial cells," Circulation Research, vol. 82, no. 5, pp. 619-628, 1998.

[118] A. Otani, H. Takagi, H. Oh, S. Koyama, and Y. Honda, "Angiotensin II induces expression of the Tie2 receptor ligand, angiopoietin-2, in bovine retinal endothelial cells," Diabetes, vol. 50, no. 4, pp. 867-875, 2001.

[119] A. Otani, H. Takagi, H. Oh et al., "Angiotensin II-stimulated vascular endothelial growth factor expression in bovine retinal pericytes," Investigative Ophthalmology and Visual Science, vol. 41, no. 5, pp. 1192-1199, 2000.

[120] L. E.H. Smith, E. Wesolowski, A. McLellan et al., "Oxygen-induced retinopathy in the mouse," Investigative Ophthalmology and Visual Science, vol. 35, no. 1, pp. 101-111, 1994.

[121] T. Alon, I. Hemo, A. Itin, J. Pe'er, J. Stone, and E. Keshet, "Vascular endothelial growth factor acts as a survival factor for newly formed retinal vessels and has implications for retinopathy of prematurity," Nature Medicine, vol. 1, no. 10, pp. 1024-1028, 1995.

[122] C. J. Moravski, D. J. Kelly, M. E. Cooper et al., "Retinal neovascularization is prevented by blockade of the renin-angiotensin system," Hypertension, vol. 36, no. 6, pp. 10991104, 2000.
[123] M. Lonchampt, L. Pennel, and J. Duhault, "Hyperoxia/normoxia-driven retinal angiogenesis in mice: a role for angiotensin II," Investigative Ophthalmology and Visual Science, vol. 42, no. 2, pp. 429-432, 2001.

[124] S. Satofuka, A. Ichihara, N. Nagai et al., "Role of nonproteolytically activated prorenin in pathologic, but not physiologic, retinal neovascularization," Investigative Ophthalmology and Visual Science, vol. 48, no. 1, pp. 422-429, 2007.

[125] H. Funatsu, H. Yamashita, T. Ikeda, Y. Nakanishi, S. Kitano, and S. Hori, "Angiotensin II and vascular endothelial growth factor in the vitreous fluid of patients with diabetic macular edema and other retinal disorders," American Journal of Ophthalmology, vol. 133, no. 4, pp. 537-543, 2002.

[126] H. Funatsu, H. Yamashita, Y. Nakanishi, and S. Hori, "Angiotensin II and vascular endothelial growth factor in the vitreous fluid of patients with proliferative diabetic retinopathy," British Journal of Ophthalmology, vol. 86, no. 3, pp. 311315, 2002.

[127] D. R. Senger, S. J. Galli, A. M. Dvorak, C. A. Perruzzi, V. Susan Harvey, and H. F. Dvorak, "Tumor cells secrete a vascular permeability factor that promotes accumulation of ascites fluid," Science, vol. 219, no. 4587, pp. 983-985, 1983.

[128] M. Larsen, E. Hommel, H. H. Parving, and H. LundAndersen, "Protective effect of captopril on the blood-retina barrier in normotensive insulin-dependent diabetic patients with nephropathy and background retinopathy," Graefe's Archive for Clinical and Experimental Ophthalmology, vol. 228, no. 6, pp. 505-509, 1990.

[129] B. Van Kooij, R. Fijnheer, J. De Boer et al., "A randomized, masked, cross-over trial of lisinopril for inflammatory macular edema," American Journal of Ophthalmology, vol. 141, no. 4, pp. 646-651, 2006.

[130] S. T. Knudsen, T. Bek, P. L. Poulsen, M. N. Hove, M. Rehling, and C. E. Mogensen, "Effects of losartan on diabetic maculopathy in type 2 diabetic patients: a randomized, doublemasked study," Journal of Internal Medicine, vol. 254, no. 2, pp. 147-158, 2003.

[131] J. H. Kim, J. H. Kim, Y. S. Yu, C. S. Cho, and K.-W. Kim, "Blockade of angiotensin II attenuates VEGF-mediated blood-retinal barrier breakdown in diabetic retinopathy," Journal of Cerebral Blood Flow and Metabolism, vol. 29, no. 3, pp. 621-628, 2009.

[132] J. A. Phipps, A. C. Clermont, S. Sinha, T. J. Chilcote, S. E. Bursell, and E. P. Feener, "Plasma kallikrein mediates angiotensin II type 1 receptor-stimulated retinal vascular permeability," Hypertension, vol. 53, no. 2, pp. 175-181, 2009.

[133] H. Nakamura, M. Yamazaki, T. Ohyama et al., "Role of angiotensin II type 1 receptor on retinal vascular leakage in a rat oxygen-induced retinopathy model," Ophthalmic Research, vol. 41, no. 4, pp. 210-215, 2009.

[134] N. Chaturvedi, A. K. Sjolie, J. M. Stephenson et al., "Effect of lisinopril on progression of retinopathy in normotensive people with type 1 diabetes. The EUCLID study group. EURODIAB controlled trial of lisinopril in insulindependent diabetes mellitus," The Lancet, vol. 351, no. 9095, pp. 28-31, 1998.

[135] Y. Shirao and K. Kawasaki, "Electrical responses from diabetic retina," Progress in Retinal and Eye Research, vol. 17, no. 1, pp. 59-76, 1998.

[136] A. J. Barber, E. Lieth, S. A. Khin, D. A. Antonetti, A. G. Buchanan, and T. W. Gardner, "Neural apoptosis in the retina during experimental and human diabetes: early onset and effect of insulin," Journal of Clinical Investigation, vol. 102, no. 4, pp. 783-791, 1998. 
[137] A. Ottlecz and T. Bensaoula, "Captopril ameliorates the decreased $\mathrm{Na}^{+}, \mathrm{K}^{+}$-ATPase activity in the retina of streptozotocin-induced diabetic rats," Investigative Ophthalmology and Visual Science, vol. 37, no. 8, pp. 1633-1641, 1996.

[138] R. E. Gilbert, D. J. Kelly, A. J. Cox et al., "Angiotensin converting enzyme inhibition reduces retinal overexpression of vascular endothelial growth factor and hyperpermeability in experimental diabetes," Diabetologia, vol. 43, no. 11, pp. 1360-1367, 2000.

[139] J. Z. Zhang, X. Xi, L. Gao, and T. S. Kern, "Captopril inhibits capillary degeneration in the early stages of diabetic retinopathy," Current Eye Research, vol. 32, no. 10, pp. 883889, 2007.

[140] Z. Zheng, H. Chen, G. Ke et al., "Protective effect of perindopril on diabetic retinopathy is associated with decreased vascular endothelial growth factor-to-pigment epithelium-derived factor ratio: involvement of a mitochondria-reactive oxygen species pathway," Diabetes, vol. 58, no. 4, pp. 954-964, 2009.

[141] S. I. Yamagishi, M. Takeuchi, T. Matsui, K. Nakamura, T. Imaizumi, and H. Inoue, "Angiotensin II augments advanced glycation end product-induced pericyte apoptosis through RAGE overexpression," FEBS Letters, vol. 579, no. 20, pp. 4265-4270, 2005.

[142] S. Satofuka, A. Ichihara, N. Nagai et al., "(Pro)renin receptormediated signal transduction and tissue renin-angiotensin system contribute to diabetes-induced retinal inflammation," Diabetes, vol. 58, no. 7, pp. 1625-1633, 2009.

[143] J. J. Mullins, J. Peters, and D. Ganten, "Fulminant hypertension in transgenic rats harbouring the mouse Ren-2 gene," Nature, vol. 344, no. 6266, pp. 541-544, 1990.

[144] C. J. Moravski, S. L. Skinner, A. J. Stubbs et al., “The reninangiotensin system influences ocular endothelial cell proliferation in diabetes: transgenic and interventional studies," American Journal of Pathology, vol. 162, no. 1, pp. 151-160, 2003.

[145] A. A. Dosso, E. Rungger-Brändle, and P. M. Leuenberger, "Ultrastructural alterations in capillaries of the diabetic hypertensive rat retina: protective effects of ACE inhibition," Diabetologia, vol. 47, no. 7, pp. 1196-1201, 2004.

[146] A. G. Miller, G. Tan, K. J. Binger et al., "Candesartan attenuates diabetic retinal vascular pathology by restoring glyoxalase-I function," Diabetes, vol. 59, no. 12, pp. 3208-3215, 2010 .

[147] P. Chen, A. M. Guo, P. A. Edwards, G. Trick, and A. G. Scicli, "Role of NADPH oxidase and ANG II in diabetes-induced retinal leukostasis," American Journal of PhysiologyRegulatory Integrative and Comparative Physiology, vol. 293, no. 4, pp. R1619-R1629, 2007.

[148] J. Z. Zhang, L. Gao, M. Widness, X. Xi, and T. S. Kern, "Captopril inhibits glucose accumulation in retinal cells in diabetes," Investigative Ophthalmology and Visual Science, vol. 44, no. 9, pp. 4001-4005, 2003.

[149] X. Zhang, M. Lassila, M. E. Cooper, and Z. Cao, "Retinal Expression of Vascular Endothelial Growth Factor Is Mediated by Angiotensin Type 1 and Type 2 Receptors," Hypertension, vol. 43, no. 2, pp. 276-281, 2004.

[150] E. Sakurai, A. Anand, B. K. Ambati, N. Van Rooijen, and J. Ambati, "Macrophage depletion inhibits experimental choroidal neovascularization," Investigative Ophthalmology and Visual Science, vol. 44, no. 8, pp. 3578-3585, 2003.

[151] C. Tsutsumi, K. H. Sonoda, K. Egashira et al., "The critical role of ocular-infiltrating macrophages in the development of choroidal neovascularization," Journal of Leukocyte Biology, vol. 74, no. 1, pp. 25-32, 2003.

[152] D. G. Espinosa-Heidmann, I. J. Suner, E. P. Hernandez, D. Monroy, K. G. Csaky, and S. W. Cousins, "Macrophage depletion diminishes lesion size and severity in experimental choroidal neovascularization," Investigative Ophthalmology and Visual Science, vol. 44, no. 8, pp. 3586-3592, 2003.

[153] N. Nagai, Y. Oike, K. Izumi-Nagai et al., "Suppression of choroidal neovascularization hy inhibiting angiotensin-converting enzyme: minimal role of bradykinin," Investigative Ophthalmology and Visual Science, vol. 48, no. 5, pp. 23212326, 2007.

[154] S. Satofuka, A. Ichihara, N. Nagai et al., "(Pro)renin receptor promotes choroidal neovascularization by activating its signal transduction and tissue renin-angiotensin system," American Journal of Pathology, vol. 173, no. 6, pp. 1911-1918, 2008.

[155] G. E. Striker, F. Praddaude, O. Alcazar, S. W. Cousins, and M. E. Marin-Castaño, "Regulation of angiotensin II receptors and extracellular matrix turnover in human retinal pigment epithelium: role of angiotensin II," American Journal of Physiology, vol. 295, no. 6, pp. C1633-C1646, 2008.

[156] F. Praddaude, S. W. Cousins, C. Pêcher, and M. E. MarinCastaño, "Angiotensin II-induced hypertension regulates AT1 receptor subtypes and extracellular matrix turnover in mouse retinal pigment epithelium," Experimental Eye Research, vol. 89, no. 1, pp. 109-118, 2009.

[157] O. Alcazar, S. W. Cousins, G. E. Striker, and M. E. MarinCastano, "(Pro)renin receptor is expressed in human retinal pigment epithelium and participates in extracellular matrix remodeling," Experimental Eye Research, vol. 89, no. 5, pp. 638-647, 2009.

[158] M. Pons, S. W. Cousins, O. Alcazar, G. E. Striker, and M. E. Marin-Castano, "Angiotensin II-induced MMP-2 activity and MMP-14 and basigin protein expression are mediated via the angiotensin ii receptor type 1-mitogen-activated protein kinase 1 pathway in retinal pigment epithelium: implications for age-related macular degeneration," American Journal of Pathology, vol. 178, no. 6, pp. 2665-2681, 2011.

[159] T. H. Wheeler-Schilling, K. Kohler, M. Sautter, and E. Guenther, "Angiotensin II receptor subtype gene expression and cellular localization in the retina and non-neuronal ocular tissues of the rat," European Journal of Neuroscience, vol. 11, no. 10, pp. 3387-3394, 1999.

[160] A. B. Cullinane, P. S. Leung, J. Ortego, M. Coca-Prados, and B. J. Harvey, "Renin-angiotensin system expression and secretory function in cultured human ciliary body non-pigmented epithelium," British Journal of Ophthalmology, vol. 86, no. 6, pp. 676-683, 2002.

[161] C. Costagliola, R. Di Benedetto, L. De Caprio, R. Verde, and L. Mastropasqua, "Effect of oral captopril (SQ 14225) on intraocular pressure in man," European Journal of Ophthalmology, vol. 5, no. 1, pp. 19-25, 1995.

[162] C. Costagliola, M. Verolino, M. Leonarda De Rosa, G. Iaccarino, M. Ciancaglini, and L. Mastropasqua, "Effect of oral losartan potassium administration on intraocular pressure in normotensive and glaucomatous human subjects," Experimental Eye Research, vol. 71, no. 2, pp. 167-171, 2000.

[163] R. F. Wang, S. M. Podos, T. W. Mittag, and T. Yokoyoma, "Effect of CS-088, an angiotensin AT1 receptor antagonist, on intraocular pressure in glaucomatous monkey eyes," Experimental Eye Research, vol. 80, no. 5, pp. 629-632, 2005.

[164] G. B. Shah, S. Sharma, A. A. Mehta, and R. K. Goyal, "Oculohypotensive effect of angiotensin-converting enzyme 
inhibitors in acute and chronic models of glaucoma," Journal of Cardiovascular Pharmacology, vol. 36, no. 2, pp. 169-175, 2000.

[165] W. H. Constad, P. Fiore, C. Samson, and A. A. Cinotti, "Use of an angiotensin converting enzyme inhibitor in ocular hypertension and primary open-angle glaucoma," American Journal of Ophthalmology, vol. 105, no. 6, pp. 674-677, 1988.

[166] M. Platten, S. Youssef, M. H. Eun et al., "Blocking angiotensin-converting enzyme induces potent regulatory $\mathrm{T}$ cells and modulates TH1- and TH17-mediated autoimmunity," Proceedings of the National Academy of Sciences of the United States of America, vol. 106, no. 35, pp. 14948-14953, 2009.

[167] T. V. Lanz, Z. Ding, P. P. Ho et al., "Angiotensin II sustains brain inflammation in mice via TGF- $\beta$," Journal of Clinical Investigation, vol. 120, no. 8, pp. 2782-2794, 2010.

[168] T. Ito, H. Yamakawa, C. Bregonzio, J. A. Terron, A. FalconNeri, and J. M. Saavedra, "Protection against ischemia and improvement of cerebral blood flow in genetically hypertensive rats by chronic pretreatment with an angiotensin II AT1 antagonist," Stroke, vol. 33, no. 9, pp. 2297-2303, 2002.

[169] S. Chen, G. Li, W. Zhang et al., "Ischemia-induced brain da-mage is enhanced in human renin and angiotensinogen double-transgenic mice," American Journal of PhysiologyRegulatory Integrative and Comparative Physiology, vol. 297, no. 5, pp. R1526-R1531, 2009.

[170] H. Yamakawa, M. Jezova, H. Ando, and J. M. Saavedra, "Normalization of endothelial and inducible nitric oxide synthase expression in brain microvessels of spontaneously hypertensive rats by angiotensin II AT1 receptor inhibition," Journal of Cerebral Blood Flow and Metabolism, vol. 23, no. 3, pp. 371380, 2003.

[171] M. A. Fleegal-Demotta, S. Doghu, and W. A. Banks, "Angiotensin II modulates BBB permeability via activation of the AT 1 receptor in brain endothelial cells," Journal of Cerebral Blood Flow and Metabolism, vol. 29, no. 3, pp. 640-647, 2009.

[172] M. A. Millan, D. M. Jacobowitz, G. Aguilera, and K. J. Catt, "Differential distribution of AT1 and AT2 angiotensin II receptor subtypes in the rat brain during development," Proceedings of the National Academy of Sciences of the United States of America, vol. 88, no. 24, pp. 11440-11444, 1991.

[173] R. Lucius, S. Gallinat, P. Rosenstiel, T. Herdegen, J. Sievers, and T. Unger, "The angiotensin II type 2 (AT2) receptor promotes axonal regeneration in the optic nerve of adult rats," Journal of Experimental Medicine, vol. 188, no. 4, pp. 661670, 1998.

[174] M. Iwai, H. W. Liu, R. Chen et al., "Possible inhibition of focal cerebral ischemia by angiotensin II type 2 receptor stimulation," Circulation, vol. 110, no. 7, pp. 843-848, 2004.

[175] T. Unger, "The role of the renin-angiotensin system in the development of cardiovascular disease," American Journal of Cardiology, vol. 89, supplement 2A, pp. 3A-10A, 2002.

[176] I. Armando, A. Carranza, Y. Nishimura et al., "Peripheral administration of an angiotensin II AT1 receptor antagonist decreases the hypothalamic-pituitary-adrenal response to isolation stress," Endocrinology, vol. 142, no. 9, pp. 38803889, 2001.

[177] S. Okuyama, T. Sakagawa, F. Sugiyama, A. Fukamizu, and K. Murakami, "Reduction of depressive-like behavior in mice lacking angiotensinogen," Neuroscience Letters, vol. 261, no. 3, pp. 167-170, 1999.

[178] A. Shekhar, P. L. Johnson, T. J. Sajdyk et al., "Angiotensin-II is a putative neurotransmitter in lactate-induced panic-like responses in rats with disruption of GABAergic inhibition in the dorsomedial hypothalamus," Journal of Neuroscience, vol. 26, no. 36, pp. 9205-9215, 2006.

[179] D. Zhu, J. Shi, Y. Zhang et al., "Central angiotensin II stimulation promotes $\beta$ amyloid production in Sprague Dawley rats," PLoS ONE, vol. 6, no. 1, Article ID e16037, 2011.

[180] J. Wang, L. Ho, L. Chen, Z. Zhao, W. Zao, and X. Qian, "Valsartan lowers brain $\beta$-amyloid protein levels and improves spatial learning in a mouse model of Alzheimer disease," Hipertension, vol. 25, no. 2, pp. 85-86, 2008.

[181] K. Zou, H. Yamaguchi, H. Akatsu et al., "Angiotensin-converting enzyme converts amyloid $\beta$-protein $1-42(\mathrm{~A} \beta(1-42))$ to $A \beta(1-40)$, and its inhibition enhances brain $A \beta$ deposition," The Journal of Neuroscience, vol. 27, no. 32, pp. 86288635, 2007.

[182] S. Shaw, M. Bencherif, and M. B. Marrero, "Angiotensin II Blocks Nicotine-Mediated Neuroprotection against $\beta$-Amyloid (1-42) via Activation of the Tyrosine Phosphatase SHP1," Journal of Neuroscience, vol. 23, no. 35, pp. 11224-11228, 2003.

[183] B. V. Bui, J. A. Armitage, M. Tolcos, M. E. Cooper, and A. J. Vingrys, "ACE inhibition salvages the visual loss caused by diabetes," Diabetologia, vol. 46, no. 3, pp. 401-408, 2003.

[184] J. A. Phipps, J. L. Wilkinson-Berka, and E. L. Fletcher, "Retinal dysfunction in diabetic ren-2 rats is ameliorated by treatment with valsartan but not atenolol," Investigative Ophthalmology and Visual Science, vol. 48, no. 2, pp. 927-934, 2007.

[185] Y. Ozawa, K. Nakao, T. Kurihara et al., "Roles of STAT3/ SOCS3 pathway in regulating the visual function and ubiquitin-proteasome-dependent degradation of rhodopsin during retinal inflammation," Journal of Biological Chemistry, vol. 283, no. 36, pp. 24561-24570, 2008.

[186] Y. Ozawa, K. Nakao, T. Shimazaki et al., "SOCS3 is required to temporally fine-tune photoreceptor cell differentiation," Developmental Biology, vol. 303, no. 2, pp. 591-600, 2007.

[187] Y. Ozawa, K. Nakao, T. Shimazaki et al., "Downregulation of STAT3 activation is required for presumptive rod photoreceptor cells to differentiate in the postnatal retina," Molecular and Cellular Neuroscience, vol. 26, no. 2, pp. 258-270, 2004.

[188] Y. Ozawa, T. Kurihara, K. Tsubota, and H. Okano, "Regulation of posttranscriptional modification as a possible therapeutic approach for retinal neuroprotection," Journal of Ophthalmology, vol. 2011, Article ID 506137, 8 pages, 2011.

[189] M. Miyoshi, K. Miyano, N. Moriyama, M. Taniguchi, and T. Watanabe, "Angiotensin type 1 receptor antagonist inhibits lipopolysaccharide-induced stimulation of rat microglial cells by suppressing nuclear factor $\kappa \mathrm{B}$ and activator protein-1 activation," European Journal of Neuroscience, vol. 27, no. 2, pp. 343-351, 2008.

[190] J. Benicky, E. Sanchez-Lemus, J. Pavel, and J. M. Saavedra, "Anti-inflammatory effects of angiotensin receptor blockers in the brain and the periphery," Cellular and Molecular Neurobiology, vol. 29, no. 6-7, pp. 781-792, 2009.

[191] M. R. Song and A. Ghosh, "FGF2-induced chromatin remodeling regulates CNTF-mediated gene expression and astrocyte differentiation," Nature Neuroscience, vol. 7, no. 3, pp. 229-235, 2004.

[192] L. E. Downie, M. J. Pianta, A. J. Vingrys, J. L. WilkinsonBerka, and E. L. Fletcher, "AT1 receptor inhibition prevents astrocyte degeneration and restores vascular growth in oxygen-induced retinopathy," GLIA, vol. 56, no. 10, pp. 10761090, 2008. 
[193] S. Okada, M. Nakamura, H. Katoh et al., "Conditional ablation of Stat3 or Socs3 discloses a dual role for reactive astrocytes after spinal cord injury," Nature Medicine, vol. 12, no. 7, pp. 829-834, 2006.

[194] E. R. Buchi, "Cell death in the rat retina after a pressure-induced ischaemia-reperfusion insult:an electron microscopic study. I. Ganglion cell layer and inner nuclear layer," Experimental Eye Research, vol. 55, no. 4, pp. 605-613, 1992.

[195] M. Berkelaar, D. B. Clarke, Y. C. Wang, G. M. Bray, and A. J. Aguayo, "Axotomy results in delayed death and apoptosis of retinal ganglion cells in adult rats," Journal of Neuroscience, vol. 14, no. 7, pp. 4368-4374, 1994.

[196] Y. Li, C. L. Schlamp, and R. W. Nickells, "Experimental induction of retinal ganglion cell death in adult mice," Investigative Ophthalmology and Visual Science, vol. 40, no. 5, pp. 1004-1008, 1999.

[197] S. Takami, Y. Imai, T. Katsuya et al., "Gene polymorphism of the renin-angiotensin system associates with risk for lacunar infarction: the Ohasama study," American Journal of Hypertension, vol. 13, no. 2, pp. 121-127, 2000.

[198] J. Hata, K. Matsuda, T. Ninomiya et al., "Functional SNP in an Spl-binding site of AGTRL1 gene is associated with susceptibility to brain infarction," Human Molecular Genetics, vol. 16, no. 6, pp. 630-639, 2007.

[199] L. H. G. Henskens, A. A. Kroon, M. P. J. Van Boxtel, P. A. M. Hofman, and P. W. De Leeuw, "Associations of the angiotensin II type 1 receptor A1166C and the endothelial NO synthase G894T gene polymorphisms with silent subcortical white matter lesions in essential hypertension," Stroke, vol. 36, no. 9, pp. 1869-1873, 2005.

[200] J. L. Wilkinson-Berka, G. Tan, K. J. Binger et al., "Aliskiren reduces vascular pathology in diabetic retinopathy and oxygen-induced retinopathy in the transgenic (mRen-2)27 rat," Diabetologia, vol. 54, no. 10, pp. 2724-2735, 2011. 


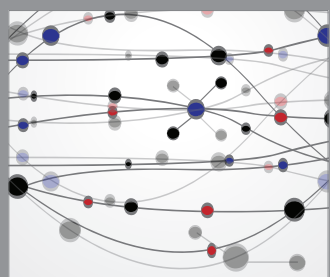

The Scientific World Journal
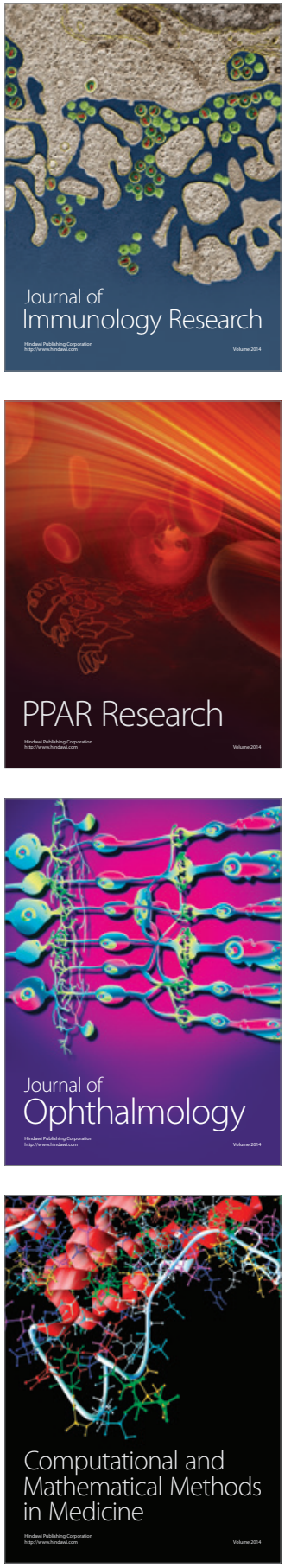

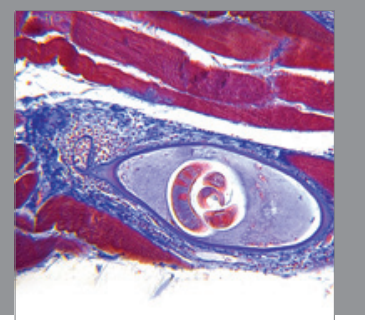

Gastroenterology

Research and Practice
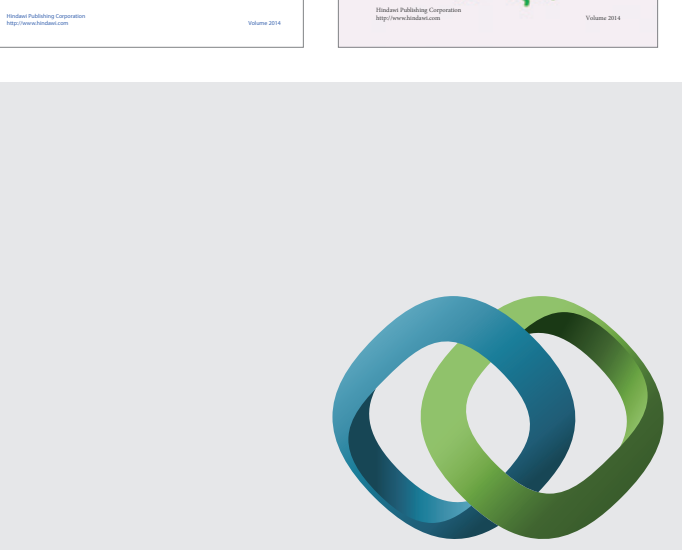

\section{Hindawi}

Submit your manuscripts at

http://www.hindawi.com
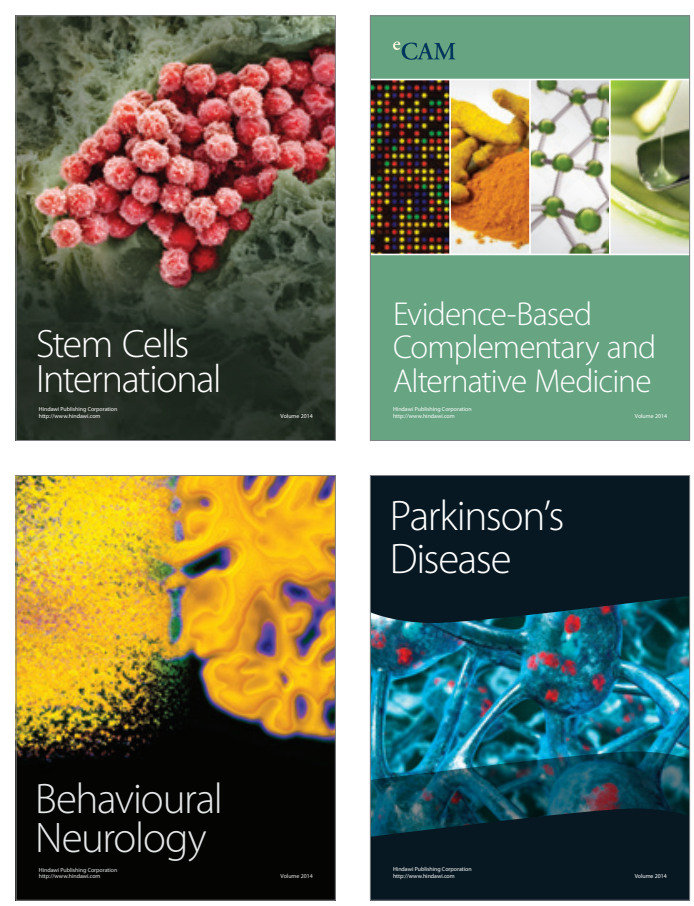

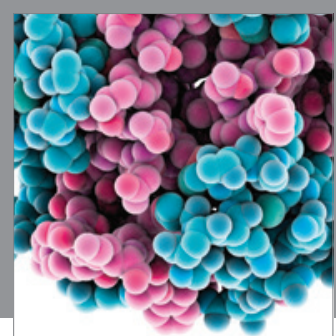

Journal of
Diabetes Research

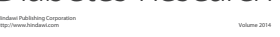

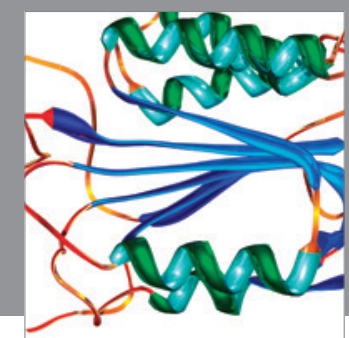

Disease Markers
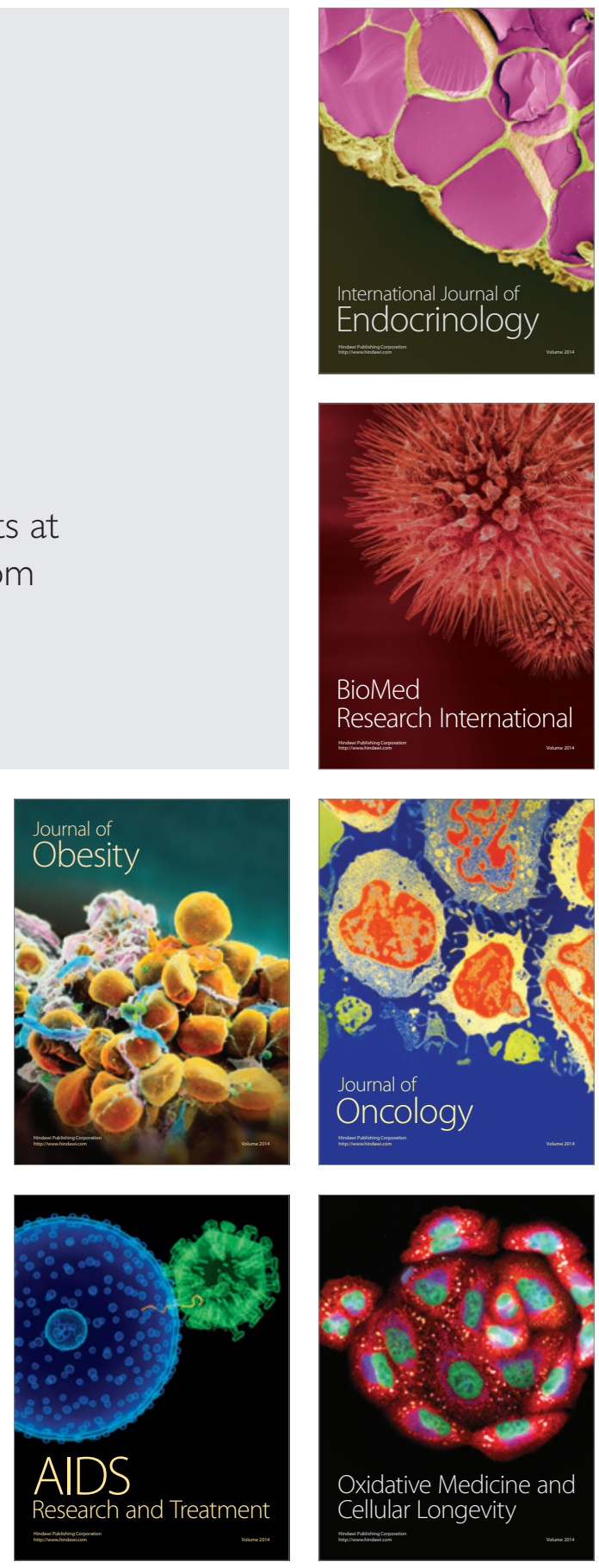